\title{
COMPUTATIONAL DESIGN AND ANALYSIS OF TENSEGRITY STRUCTURES
}

\author{
A B S S T R A C
}

The paper presents the application of computational tools in design and analysis of integrally tensioned (tensegrity) structures. The shaping process of this specific type of spatial structures is determined by consideration of form-structure interrelation. Therefore, the sustainable approach to their design implies the application of tools which could both represent geometry and simulate their physical behaviour. With respect to this, in the research we tested the application of computational tool Fasttens for design of tensegrity structures. Fasttens programme is based on the computational procedure for non-linear analysis of tensegrity systems originally developed by Miodrag Nestorović. In order to run the original programme written in Turbo Pascal, we performed emulation, using emulator software DOSBox. We tested the application of the tool in the design of concrete tensegrity structure. Presented design and numerical experiment confirmed the effectiveness of the proposed approach.

\section{Jelena Milošević}

University of Belgrade - Faculty of Architecture

KEY WORDS

Đorđe Nedeljković

University of Belgrade - Faculty of Civil Engineering

TENSEGRITY STRUCTURES

STRUCTURAL DESIGN

COMPUTATIONAL DESIGN

COMPUTATIONAL ANALYSIS

FASTTENS 


\section{INTRODUCTION}

From the first Richard Buckminster Fuller's ideas, ${ }^{1}$ David Georges Emmerich's studies $^{2}$ and Kenneth Snelson's sculptures, ${ }^{3}$ integrally tensioned (tensegrity) systems have attracted attention and gained interest of designers, engineers and scientists. Lightness, elegance and distinguishable aesthetics of continuously spatially tensioned meshes broken by separated rods, then the capacity of creation diverse, complex forms and above all, efficiency and economy aroused from the less material consumption undoubtedly are the advantages of these spatial structures. Their morphology that enables simple, typical production of elements and application of universal production techniques to achieve diverse configurations was suitable for industrial production. ${ }^{4}$ The age of digital design and production brought opportunities in terms of innovative design methods and technologies, mass-customisation in production contributing to diversity and complexity of designs. ${ }^{5}$ And smart materials with advanced properties, facilitate resolution of the problem of collapse, or enable creation of regenerative and adaptive structures. ${ }^{6}$

The sustainable way of designing structures for which the principle form follows force is applied involves the application of form-finding tools that facilitate shaping through modelling of physical performances. The principle that implies that shape is determined by force and vice versa is especially true for axially stressed structures such as tensegrity, a type of discrete spatial structures stressed both in tension and compression. Form-finding is the process of 'finding (optimal) shape that represents (or approximates) the state of the static equilibrium, ${ }^{77}$ and according to Haber and Abel (1982) 'initial equilibrium problem.' Form-finding is not a random search, but experiment or simulation based on physical principles set within defined boundary conditions. And in the case of tensegrity structures, that exhibit geometrically non-linear behavior and large displacements under loading, it is important to bear in mind that their prestressed shape and deformation under loading are the results of the combined effects of the geometric parameters that determine the initial configuration of the structure, the level of prestress applied to cables, and the material properties of the component members of the structure.

Independently of the applied technique - experiments with physical models or digital simulations ${ }^{8}$ the roles of form-finding tools are shape exploration and structural behavior estimation, implying that they are both conceptual and analytical devices. With respect to this, these tools should be capable to simulate physical processes and flexible for design research and fast production of alternative designs, especially important for the conceptual design. Although experiments with physical models are still interesting for the explorations in the 
initial design phase and for the education, since the last decades of the twentieth century, due to the developments of CAD (Computer Aided Design) and virtual modelling techniques, the application of computational tools is dominant. Computational tools simulate behavior of the physical models, enabling more sophisticated, precise, efficient, reliable simulations, and flexible interactively based researches. They also allow far simpler manipulation with the models, variations of parameters (materials, load cases that have a dominant effect on shape, boundary conditions, etc.), and their digital outcomes can be directly used for structural analysis as well as for digital production. The development of new applications designated for the design, and improvement of the existing (especially in terms of creation more user-friendly environments), transformed the position of these tools from a specialised to more available design resources, contributing to the expended interest of designers for unconventional spatial structures, including tensegrity.

A number of procedures and tools have been developed for design of tensegrity structures. Following the works of the 1960s pioneers, the contribution in the development of tensegrity structures is represented in the various researches. ${ }^{9}$ Since the 1960s, the researchers are focused on the development of numerical methods and computational tools. Generally, both geometric stiffness and dynamic equilibrium methods ${ }^{10}$ are applicable for form-finding of tensegrity structures. Many methods were formulated over the past decades based on dynamic-relaxation, ${ }^{11}$ force density, ${ }^{12}$ kinematic formulation, ${ }^{13}$ and minimisation function. ${ }^{14}$ The tools created on the basis of these methods are developed both in engineering research groups (e.g. force density method, dynamic relaxation) and in the research group involved in physic based animations or gaming software (e.g. particle spring). Geometric stiffness methods are developed from the traditional methods of finite element analysis. They are capable of precise calculations and independent from material, only the geometric stiffness is represented in them. An example of application of these methods within design software is RhinoMembrane (IxRay 2014), a plug-in for Rhinoceros (Robert McNeel \& Associates n.d.), which (from the Version 1.22) implements a tensegrity form-finding algorithm based on force density method. Dynamic equilibrium methods (e.g. dynamic relaxation and particle spring) reduce the problem of dynamic to the problem of static equilibrium, so that the solution is equivalent to a static equilibrium. An example that explores double layer tensegrity grids and integrates dynamic relaxation with associative modelling tools is represented in the work of Gustav Fagerstorm (2009). On the other hand, form-finding with particle-spring systems is widely used in computer graphics to produce visually correct interactive animations. The research carried out at Massachusetts Institute of Technology (MIT) into the sustainability of particle- 
spring systems as design tool has demonstrated their usefulness in finding the form of tensioned structures in a real-time environment. ${ }^{15}$ The research of Tristan D'Estree Sterk and Andrew Payne about tensegrity form-finding with animation tools represents one example. ${ }^{16}$ Another example of the tool for formfinding of tensegrity structures based on particle-spring system is Java Struck applet developed by Gerald De Jong (1998). The application of this applet for genereting three-dimensional tensegrity structures from two-dimensional topologies was conducted by Thomas Seebohm (2008). An example of the tool for interactive simulation, form-finding, optimisation and constraint solving is Kangaroo Physics by Daniel Piker (Piker n.d.). Kangaroo Physics is a plug-in for Grasshopper (Davidson n.d.), graphical editor for Rhinoceros, that consists of a solver library and a set of Grasshopper components including those for tensegrity structures.

This paper focuses on the application of computational tool in design and analysis of tensegrity structures. The previous brief review infers that calculating the shape of tensegrity structure in digital environment requires form-finding procedures that can establish 'a geometry compatible with selfstress state. ${ }^{17}$ Currently, this functionality is not supported within the majority of conventional CAD software. With respect to this, in this research we tested the application of computational programme Fasttens created for design of tensegrity structures. The programme is based on the computational procedure that enables non-linear analysis of integrally tensioned (tensegtity) structures developed by Dr Miodrag Nestorović (1990).The original algorithm was written in Pascal and used on IBM PC in 1990. For the purpose of this research, we needed to perform the emulation of the Fasttens programme. Starting from the hypothesis that the programme should be three-dimensional tool for research that can be used in conceptual design phase, and that the tool should find approximate shape and evaluation of the aesthetic, spatial and structural aspect of the tensegrity structure, we tested the application of the tool in the design of specific tensegrity structure. The results confirmed the effectiveness of the proposed approach, benefits of the application of the tool in the design process, and enabled us to detect advantages, as well as weakneses of the tool which will be improved through further development.

\section{METHOD AND TOOL}

Methods of computational form-finding are numerical procedures that simulate the physical performance of the system, a numerical verification of the physical experiments. With respect to this, the method and tool for simulation of tensegrity structures should be able to represent phenomena of coherence of the forces of 
pressure and tension characteristic for these systems. This logic is derived from the nature. To build natural systems, nature uses equilibrium between tension and pressure, and the law that elements subjected to pressure are usually heavier and larger than tensioned components. The previous is necessary because the components subjected to the tension should be strong enough to withstand the imposed loads, while the components exposed to the pressure should be thicker to prevent their buckling as well. In every structural system, there must be a continuity that allows force flow. In most of the man-made structures, this continuity is achieved by the components exposed to the pressure, with the partial inclusion of the tensile components where they cannot be avoided. In the tensegrity system, the continuity is achieved by a continuous mesh of tensioned elements, while the elements subjected to pressure are discontinuous. Or as Fuller defined 'the system of integrally tensioned (tensegrity) entities is established by the interaction between discontinuous components exposed to the pressure and continuous tensile components that form a stable shape in space. ${ }^{18}$ So, the tool for form-finding of tensegrity structures should be able to simulate tensional integrity or floating compression, as illustratively termed by Kenneth Snelson. In any case, it is important for the tool to correctly represent the structural principle behind the structures in which the tensile components are continuous, and compression components discontinuous. It should be noted that in the definition, the terms rod and cable (that will be used in the paper) were not used because the components are not always rods and cables. For example, tensile membrane could be used for construction in the case of textegrity or pneumatic (inflated) tubes for compressed elements in the case of tensairity structures. ${ }^{19}$

The analogies of the behavior of tensegrity structure and other systems such as balloons, spider webs, fish webs, etc., could be made. In this respect, Fuller showed similarity of the shape of tensegrity structures with the balloons and air-supported structures. ${ }^{20}$ The air in the balloon is under the higher pressure in comparison to the air pressure of its surrounding. It presses into the field opposite to the membrane that is pressing towards the inside. Similarly, in tensegrity structure made of linear elements, rods push into the field, and cables towards interior (like balloon membrane). If the air pressure in the balloon increases, the tensile forces in the membrane increase and it becomes more difficult to deform the balloon. By increasing the force in the components of the tensegrity structure made of linear elements, its strength and the resistance to the external load are also increased. Vibrations are almost always transferred to the whole balloon. Similar behaviour can be noticed in the most tensegrity structures made of linear elements. If the tensegrity structure is pressed downward, it deforms, but it recovers its initial position when the action of the 
forces terminates. It is similar in the case of the balloon. If the pressure is strong enough, the tensegrity structure collapses, and under the sufficiently strong impact, the balloon can also be broken. Reverse analogies are also possible. ${ }^{21}$ The concept of tensegrity was expended to the field of biology by Donald E. Ingber (1985), to explain the behavior of the biological systems. The work on tensegrity led him to investigate the role of mechanical forces in biological development, and moreover, to propose it as the fundamental design principle and mechanism that governs how living systems are structured, from individual molecules and cells to whole tissues, organs and organisms. ${ }^{22}$

The Procedure for the Analysis

of Tensegrity Structures

The procedure for non-linear analysis of tensegrity structures developed by $\mathrm{Dr}$ Miodrag Nestorović is explained in Integrally Tensioned (Tensegrity) Structural Systems I and II (Integralno zategnuti (Tensegriti) konstruktivni sistemi I i II). The procedure belongs to dynamic equilibrium methods, and describes the behavior of tensegrity structures that are extremely nonlinear both in terms of geometry and stiffness, by iterative algorithm.

The development of the algorithm and its computer implementation required treatment of several aspects of the problem - topology, linearisation, relaxation and local equilibrium. The topology describes all relations between the elements of the system, and resolving this aspect of the problem implied the creation of relation database generated through the arranged data that are accessed by indices. This system solution avoids more degrees of nested loops, enabling direct data access and efficient program implementation. Linearisation of the problem is realised by the application of the iterative calculation that implies estimation of the reaction (force) caused by the arbitrary node displacement, and then its addition to the anterior node force, resulting in new external (residual force). If the intensity of thus obtained residual force is less than the remaining external force from the initial configuration, by successive replacements of the current into the initial configuration, we obtain a smaller residual forces in nodes, until the moment in which the largest residual force in a node is less than the technically determined boundary residual force (that cannot affect the accuracy of the solution in technical terms), which is considered as the end of the process, and obtained forces and displacements as actual/real values. Instead of arbitrary node displacement, the application of the displacement obtained by the linearisation of the local equilibrium conditions the number of the iterations could be reduced. Considering that the effect of the force in a node is transferred to its neighbours, and that transferred force performs displacements of these adjacent nodes in the following iterations causing relaxation of the subject 


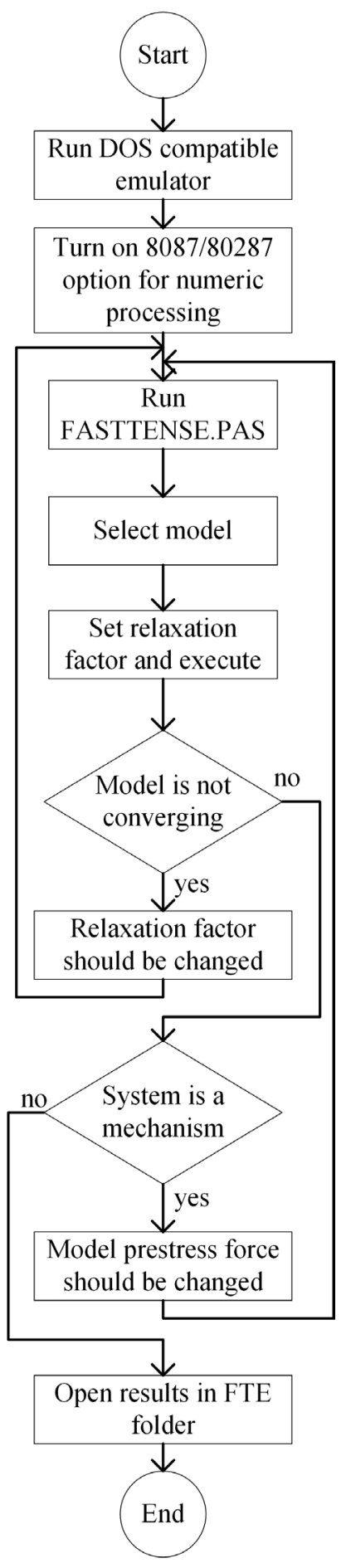

Figure 1. Fasttens execution protocol

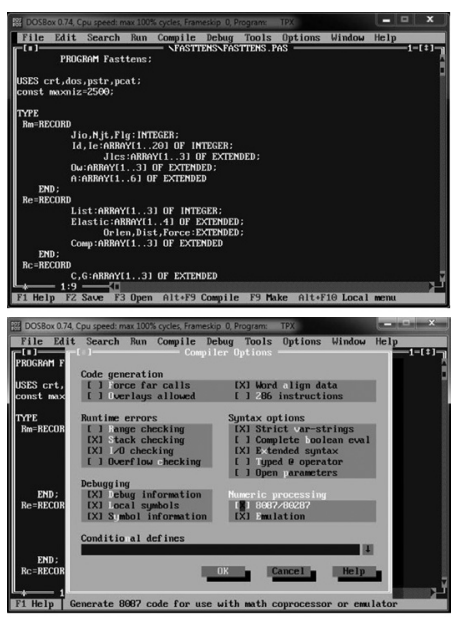

Figure 2. Emulation of Fasttens by DOSBox emulator

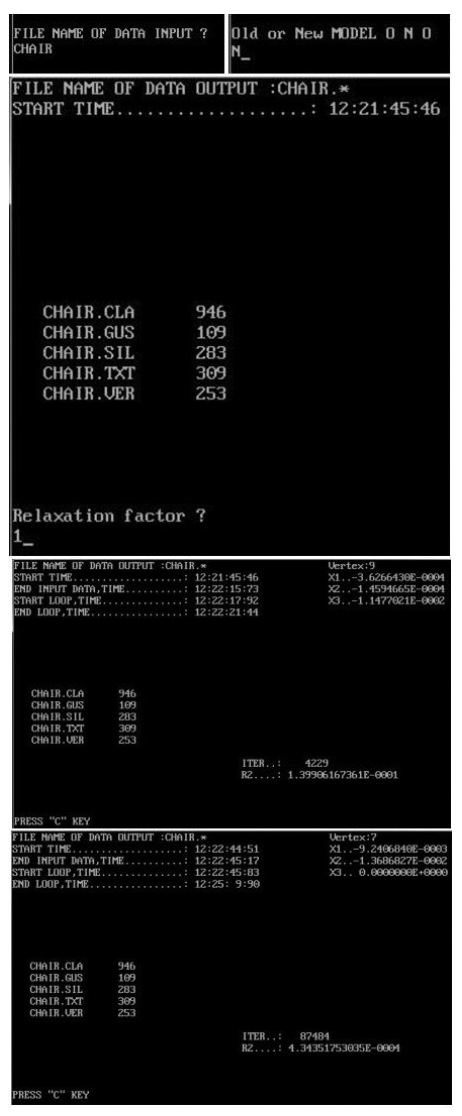

Figure 3. Working process in Fasttens 
node, it is obvious that the node will move more than it is calculated from the conditions of the local equilibrium. Therefore, it is necessary to increase thus calculated displacement by relaxation factor. The relaxation factor improves convergence, and theoretically is between 1 and 2; however, in the case of tensegrity structures, the applied factor should be between 1 and 1.5 - at the beginning of the process -1.5 and 1 when approaching the solution. In the iterative process, some elements can be initially compressed, and then tensioned or they can remain compressed, which results in the change of geometry, and therefore, a change in the stiffness. Since it is a local and temporary occurrence, the local mechanism cannot be solved by the application of the global stiffness matrix. In the case when there are no inverse stiffness matrices, the node is locally unstable, i.e. with its environment it represents infinitesimal mechanism. The analysis uses $3 \times 3$ matrices for the equilibrium condition of each node, thus giving forces in the elements that are connected in the node. Repeating this procedure with a special infinitesimal mechanism, which allows an element that cannot be compressed to be only temporary excluded from the action, and to reactivate when it becomes tensioned again during the iteration.

The Implementation of the Algorithm for

the Analysis of Tensegrity Structures

The algorithm for nonlinear analysis of integrally tensioned systems is implemented as a Turbo Pascal application Fasttens. The execution protocol of Fasttens is summarized by the flowchart in Figure 1. Since the programme was written for the $\mathrm{x} 86 \mathrm{PC}$ architecture computer processor, an emulator which simulates it is necessary for programme execution. In this research, DOSBox emulator is used (Figure 2), which emulates an Intel x86 PC, complete with sound, graphics, mouse, joystick, model, etc.

Before running Fasttens, the following steps are necessary:

- Download the archive which contains Turbo Pascal IDE (Integrated Development Environment) and unpack it in designated TP folder (for example c: $\backslash t p \backslash)$. The authors recommend that the Turbo Pascal archive from the appendix is used since it already contains all the additional libraries required by the programme.

- In the installation folder, a file named DOSBox version_number Options. bat should be modified so that the following lines are added at the end (if the TP folder is c: $|t p|)$ :

mount d c: $\mid t p \backslash$

$\mathrm{d}$ :

cd bin

tpx 
After running DOSBox, Turbo Pascal IDE is active. The program requires an option for $8087 / 80287$ numeric processing to be active, which can be found under Options/Compiler/Numeric processing.

Once loading and running file FASTTENSE.PAS, the user is prompted to select the name of the model, which must be the same as the name of four input files. Afterwards, the user can choose between new and old model, where the former starts a new calculation, and the later option continues previously stopped calculation. Finally, a relaxation factor is defined, after which the programme starts calculation in a terminal. The procedure can be halted in any iteration, and current undistributed force in the system, also the deformation of the current node can be read. When the system reaches equilibrium, calculation is finished, and the user is prompted to press a key which closes the terminal. The described process is illustrated by Figure 3. The parameters in the iterative process of form-finding of tensegrity structure are relaxation factor and relative prestress force.

\section{DESIGN EXAMPLE}

The design task was to propose innovative design for chair, unconventional in terms of form, structure, material and design search process. Chair design has always been challenging for designers and architects. Two main objectives of this design experiment were:

- to test of the design approach that implies inclusion of data on structural performances in design process and

- to test the application of the developed computational tool in the design context.
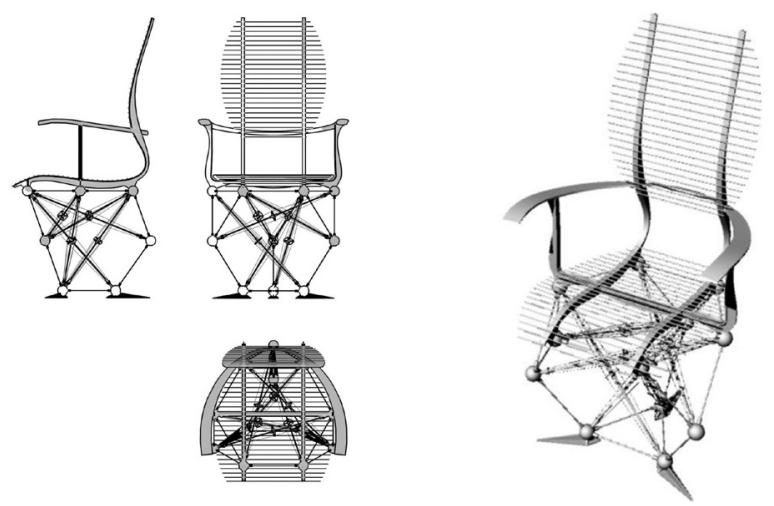

Figure 4 . Tensegrity chair designed by Nebojša Vortovšek at the Spatial Structures course 
The design process included the following steps literature review, anthropometric study with the focus on control of dynamic movements and position of the human figure using the usual anthropometric units. Design development was based on the approach proposed by David Georges Emmerich (1972), who hierarchically divided the creation process into five phases: 1) morphological (imaginary), 2) metric (dimensional), 3) mechanical (stabilisation), 4) physical (calculative), and 5) technological (performative). According to Emmerich, this division is analogous to the evolution of our ability of spatial perception. Following this line of thoughts, formally complex but optimal design solution, illustrated in Figure 4, emerged in synthetic design process characterised by interaction of form, structure and material. Distinctive aesthetical effect was accomplished using tensegrity structure as a support of anatomically designed chair seat. The result is rational, light structure that uses minimum of material and reveals underlying structural principles. Elegant but expressive chair design imposed importance of the issues of structure and materialisation. Regarding that, the approach which included the application of computational tools ensured an efficient design. This experiment indicates the potential of involving different technologies in the design process, and that the development of new product should be synthetic process with equal consideration of all design aspects form, functionality, structure, materialisation and production technology.

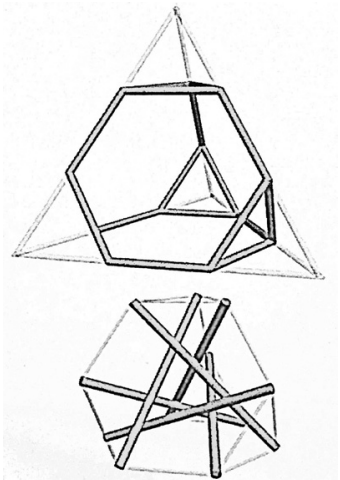

Figure 5. Truncated tetrahedron and truncated tetrahedron tensegrity structure
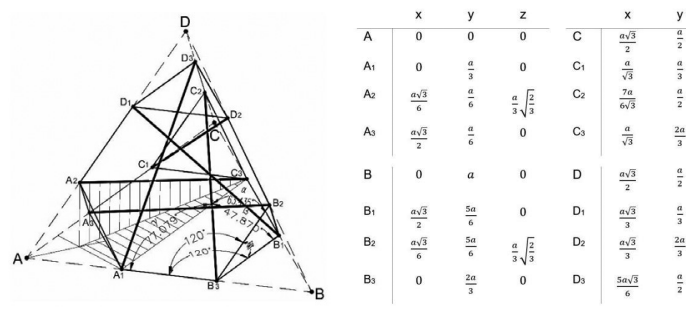

Figure 6 . Geometry of the tensegrity structure that supports the chair seat - truncated tetrahedron and its spatial coordinates 


\section{Genesis of Tensegrity Structure}

The geometry of the tensegrity chair support was generated starting from the platonic polyhedron, truncated tetrahedron given in Figure 5. The geometric model serves as the best check for the calculation of the longitudinal relations, angles, determination of interaction between the rods and treads, and node geometry. The computer analysis began with the establishment of the dependence of the geometric coordinates of the spatial system on the length of the edge of the tetrahedron which triangular base $\mathrm{ABC}$ lies in the horizontal plane. The vertices are marked with numbers $\mathrm{A}, \mathrm{B}, \mathrm{C}$ and $\mathrm{D}$, the length of the edge of the tetrahedron is $a$, and the chosen coordinate start $\mathrm{O}$ is in point $\mathrm{A}$.

The vertices obtained by trimming are marked with the latter of the trimmed vertices and index number. By the simple calculation, we can obtain information on the coordinate dependence illustrated in Figure 6 . The analysis of the spatial node implied an analysis of the angles that cover the axial directions of the structural elements in a single node of structure, having in mind that in Platonic polyhedral all nodes are equal. The starting assumption was that the materialisation of the nodes will be by spherical elements, which is common solution in the case of discrete spatial structures.

Angles in the node $\mathrm{B}_{3:}$

$$
\begin{aligned}
& <\mathrm{A}_{1} \mathrm{~B}_{3} \mathrm{~B}_{2}=<\mathrm{A}_{1} \mathrm{~B}_{3} \mathrm{~B}_{1}=120^{\circ} \\
& <\mathrm{B}_{1} \mathrm{~B}_{3} \mathrm{~B}_{2}=60^{\circ} \\
& <\mathrm{C}_{2} \mathrm{~B}_{3} \mathrm{~B}_{2}=63,435^{\circ}=\mathrm{a} \\
& <\mathrm{C}_{2} \mathrm{~B}_{3} \mathrm{~B}_{1}=47,780^{\circ}=\mathrm{b} \\
& <\mathrm{C}_{2} \mathrm{~B}_{3} \mathrm{~A}_{1}=77,079^{\circ}=\mathrm{g}
\end{aligned}
$$

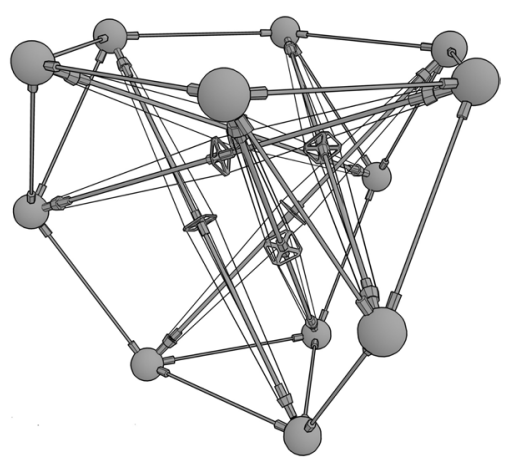

Figure 7. The model of the tensegrity structure that supports the chair seat

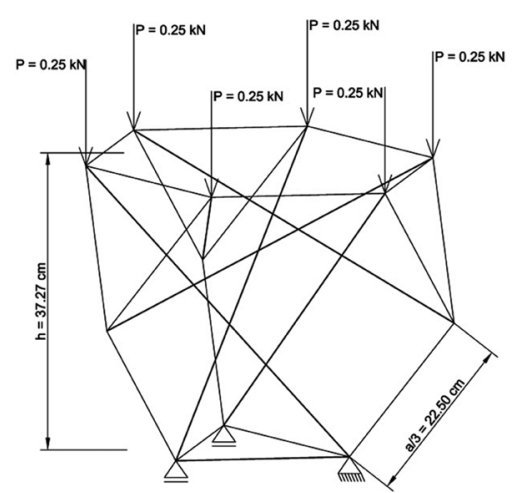

Figure 8 . The static scheme of the tensegrity structure that supports the chair seat 
If the side of the tetrahedron is $\mathrm{AB}=\mathrm{AC}=\mathrm{AD}=\mathrm{BC}=\mathrm{CD}=a$, then we have 18 tensioned cables $\mathrm{A}_{1} \mathrm{~A}_{2}=\mathrm{A}_{1} \mathrm{~A}_{3}=\mathrm{A}_{1} \mathrm{~B}_{3}=\mathrm{A}_{2} \mathrm{~A}_{3}=\mathrm{A}_{2} \mathrm{D}_{1}=\mathrm{A}_{3} \mathrm{C}_{1}=\mathrm{B}_{2} \mathrm{~B}_{1}=\mathrm{B}_{1} \mathrm{~B}_{3}=\mathrm{B}_{1} \mathrm{C}_{3}=\mathrm{B}_{2}$ $\mathrm{B}_{3}=\mathrm{B}_{2} \mathrm{D}_{2}=\mathrm{C}_{1} \mathrm{C}_{2}=\mathrm{C}_{1} \mathrm{C}_{3}=\mathrm{C}_{2} \mathrm{C}_{3}=\mathrm{C}_{2} \mathrm{D}_{3}=\mathrm{D}_{1} \mathrm{D}_{2}=\mathrm{D}_{1} \mathrm{D}_{3}=\mathrm{D}_{2} \mathrm{D}_{3}=a / 3$, and 6 compressed $\operatorname{rods} \mathrm{A}_{1} \mathrm{D}_{3}=\mathrm{A}_{2} \mathrm{C}_{3}=\mathrm{A}_{3} \mathrm{~B}_{2}=\mathrm{B}_{3} \mathrm{C}_{2}=\mathrm{C}_{1} \mathrm{D}_{2}=a / 3 \sqrt{ } 5$.

\section{The Analysis of Tensegrity Structure}

In design proposal, triangular face of truncated tetrahedron is used as lower basis of the structure, and on the upper hexagonal face seat is placed (Figure 7). As described model of the spatial structure is composed of 24 linear elements, of which 18 tensioned cable elements are $18.5 \mathrm{~cm}$, and 6 compressed rod elements are $46.3 \mathrm{~cm}$. Linear elements are connected with 12 nodes. The structure is supported in three node points (vertices of lower basis), and loaded in six node points (vertices of the upper basis) with the concentrated forces of $\mathrm{P}=0.25 \mathrm{kN}$. Static scheme of the analysed tensegrity structure is given in the Figure 8. In the next steps form-finding of the equilibrium structure was conducted, and displacements of the initial geometries were calculated.

The analysis was also done for the structure which has the same geometry, with the difference that the hexagonal face was used as lower basis, i.e. the structure was supported in six node points, and vertical load of equal magnitude was distributed and applied in the node points of triangular face.

\section{Results and Discussion}

The results of the analysis of spatial structures done by Fasttens are presented in Figure 9.

It can be noted that the structure supported in six points has better structural performances. However, the aesthetics of this structure was unacceptable. This brings us to the problem that it is not always easy to apply the results of simulations and form-finding in design. Although simulations represent very direct way to find form, which by its nature passed through the process of optimisation, design solution cannot be seen only in relation to structural design factors, but other design aspects must be included. Readiness to compromise and to adapt the condition of simulation setting to complex design conditions in order to realise a good solution in every sense is important for this approach. And the synthetic approach to design is tendency which insists on a concept of object as organic whole created by balancing diverse requirements, through complex interaction of form, function, structure and material. The essential feature of this approach is rationality, conducted by the search of solution that can meet the maximum requirements. Considering that, the choice of tensegrity 

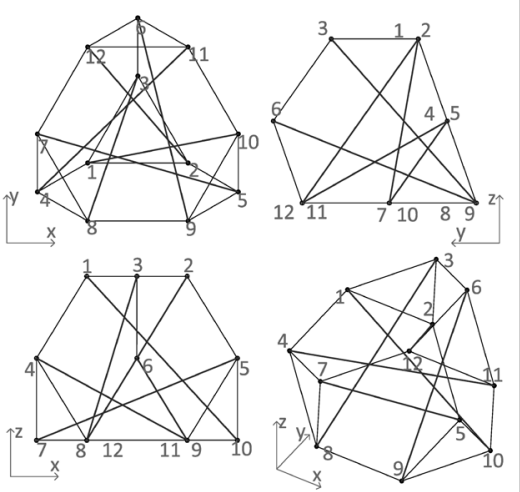

19 Element : 6- $9-$

Orlen : 5.591E-8001 Dist : 5.599E- -8001 Force :-9.397E-8001

28 Element $: 12-$
Orlen : $5.591 \mathrm{E}-0801$ Dist :

21 Element: $11-\quad 4$ -

Orlen : 5.591E-0801 Dist : 5.590E-8001 Force :-9.395E-0801

22 Element : 8- $3-$
Orlen : $5.591 \mathrm{E}-0001$ Dist : $5.590 \mathrm{E}-0001$ Force :-1.530E+0800

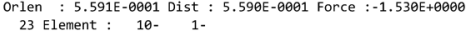

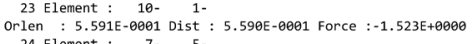

24 Element : $\quad 7-\quad 5-$
Orlen : $5.590 \mathrm{E}-0001$ Dist : $5.590 \mathrm{E}-8001$ Force : $-9.447 \mathrm{E}-0001$

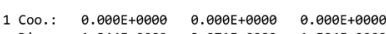

Disp: $\quad-1.344 \mathrm{E}-0002 \quad 3.071 \mathrm{E}-0002 \quad-1.504 \mathrm{E}-0002$

2 Coo.: $2.500 E-0001$ O.

Disp: $-2.0170 .0002-2.744 E-0002-1.497-0002$

$\begin{array}{llll}3 \text { Coo.: } & 1.250 E-0001 & 2.165 E-0001 & 0.000 E+8000 \\ \text { Disp: } & 3.355 \mathrm{E}-0002 & -4.197 \mathrm{E}-8003 & -1.485 \mathrm{E}-8002\end{array}$
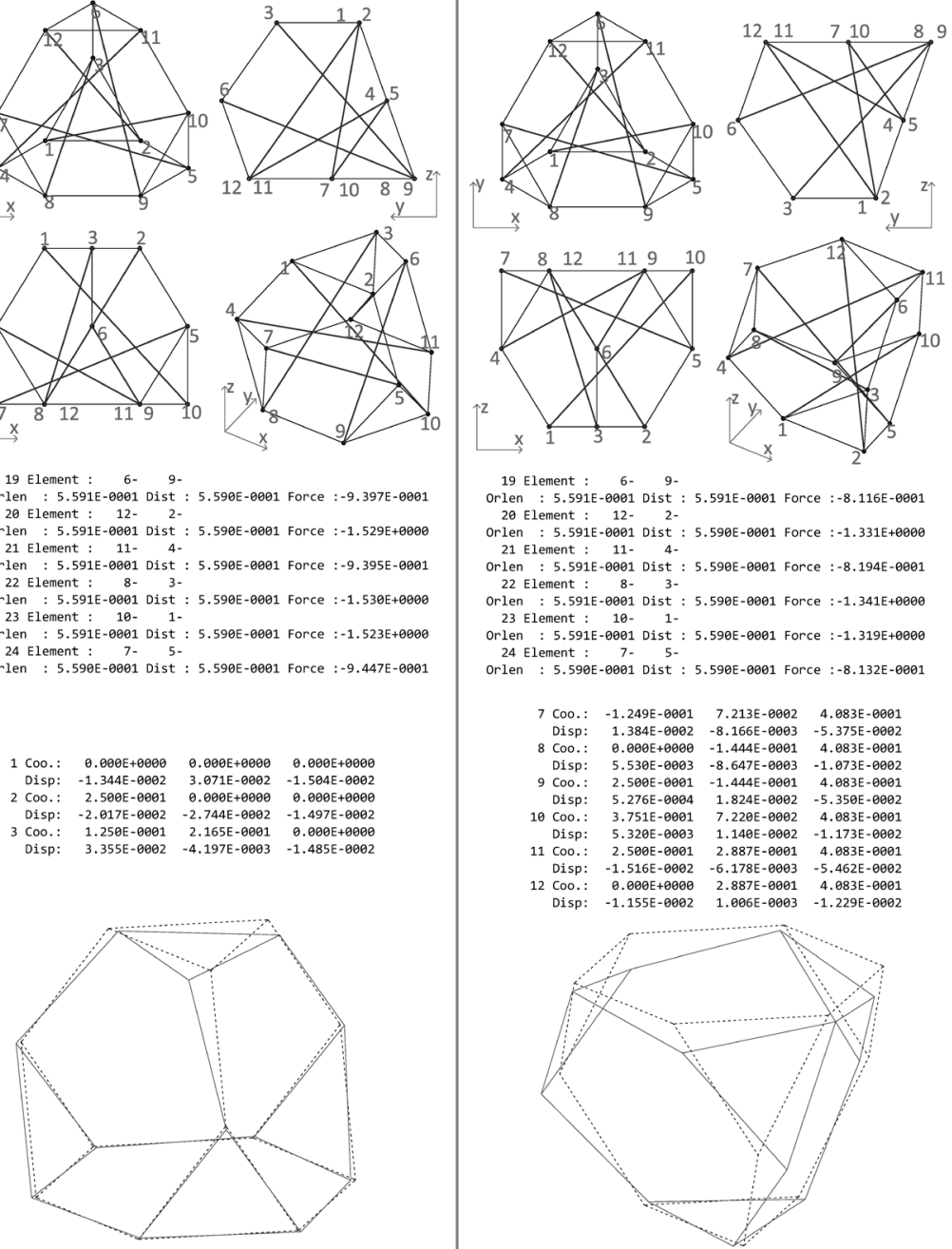

19 Element : $6-99-$
Orlen : 5.591E- 9001 Dist : 5.591E-0001 Force :-8.116E-8001

Orlen : 5.591E-8001 Dist : $5.591 \mathrm{E}-0001$ Force :-8.116E-0001
20 Element : 12- 2-

Orlen : 5.591E-8001 Dist : $5.590 \mathrm{E}-0001$ Force :-1.331E+8000

21 Element : $11-4$ -
Orlen : 5.591E-8001 Dist : $5.590 \mathrm{E}-0001$ Force :-8.194E-8001

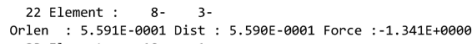

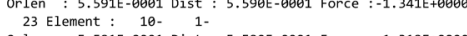

Orlen : 5.591E-e001 Dist : $5.590 \mathrm{E}-0001$ Force :-1.319E+e000

Orlen : : 5.590E-8001 Dist : 5.590E-0001 Force :-8.132E-0001

7 Coo.: $\quad-1.249 \mathrm{E}-0001 \quad 7.213 \mathrm{E}-0002 \quad 4.083 \mathrm{E}-8001$

\begin{tabular}{llll}
7 Coo.: & $-1.249 E-0001$ & $7.213 E-0002$ & $4.083 E-0001$ \\
Disp: & $1.384 \mathrm{E}-0002$ & $-8.166 \mathrm{E}-0003$ & $-5.375 \mathrm{E}-0002$ \\
\hline
\end{tabular}

8 CoO.: $\quad$ 0.

$\begin{array}{cccc}\text { Disp: } & 5.530 E-0003 & -8.647 \mathrm{E}-0003 & -1.073 \mathrm{E}-0002 \\ 9 \mathrm{COO}: & 2.580 \mathrm{E}-0001 & -1.444 \mathrm{E}-0001 & 4.083 \mathrm{E}-0001\end{array}$

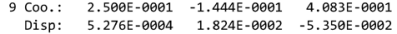

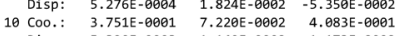

$\begin{array}{lllr}10 \text { Coo:: } & 3.751 E-\theta 001 & 7.220 E-\theta 002 & 4.083 E-\theta 001 \\ \text { Disp: } & 5.32 \theta E-\theta \theta 03 & 1.14 \theta E-\theta 0 \theta 2 & -1.173 E-\theta \theta \theta 2\end{array}$

\begin{tabular}{llll}
11 Coo.: & $2.580 \mathrm{E}-8001$ & $2.887 \mathrm{E}-0001$ & $4.083 \mathrm{E}-8001$ \\
\hline & &
\end{tabular}

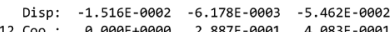

$\begin{array}{rrrr}12 \text { Coo.: } & 0.080 \mathrm{E}+\theta 000 & 2.887 \mathrm{E}-\theta 001 & 4.083 \mathrm{E}-0001 \\ \text { Disp: } & -1.155 \mathrm{E}-0002 & 1.006 \mathrm{E}-\theta 003 & -1.229 \mathrm{E}-\theta 002\end{array}$

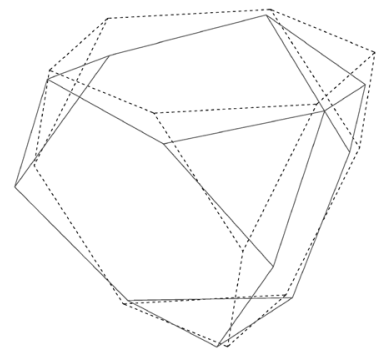

Figure 9. Results of the analysis of the tensegrity structure 
structure was done in the way that best fits all conditions and achieves harmony with all design aspects, and the design took several iterations until technical and aesthetical requirements were finally satisfied. It should be pointed that possibility of diagnostics of structural performance of the design offers opportunities in terms of efficiency and economy of the proposed solution. Respectively, working in common framework is quite attractive.

In designing tensegrity structures, the inclusive approach of shaping and analysis is essential, since aesthetical and mechanical decisions cannot be separated. To enable fully integrated cross-disciplinary investigation between architecture and engineering teams, additional software components are needed. These programme components should augment standard computational design environments by assigning the physical (material) attributes to the geometric substrate, i.e. they must address material properties (elasticity), gravity (selfweight), external loads, geometric constraints between elements and userdefined boundary constraints. With respect to this, Fasttens programme applied in this research supports design exploration of complex tensegrity structures. It enables structural evaluation and handles large numbers of elements. Although Fasttens is not adequate full design and engineering resolution, it is an example of a programme that extends computation beyond the inert representation realm characteristic of standard CAD tools. Fasttens is introduced here as an example of the type of design tool necessary to explore statically indeterminate structures. The tool facilitates the testing of the design solution, the comprehension of its behaviour/performance due to the applied loads, and stress and strain estimation in the iterative process. The application of this tool facilitates the use of structural logic to tune a form towards an 'optimal' solution. This approach to design not only initiates early stage interdisciplinary collaboration but also helps to bridge the divide between architectural design conception and construction.

\section{CONCLUSION}

Computational form-finding tools that simulate the behaviour of the equilibrium physical models, are useful vehicles for design explorations of structural forms, visualisation, and mediums of the communication between architects and engineers in the collaborative design of tensegrity structures. Currently, the role of these tools in design process changed from problem-solvers to stimulating, interactive design tools for form-improvement or form-exploration. Since they replicate real physical situations, provide insight and facilitate understanding of the mechanical principles underlying behaviour of the real structures, the application of these tools enables architects to directly participate in the shaping of the structural forms. This kind of connection between structural and 
visual researches through this medium have advantage in comparison to the conventional design approach, because these simulations have real character, introduce physical behavior, and demonstrate structural weaknesses and advantages of the designs.

Despite the impression left by simulation tools, the challenge is to apply them actively in the process of form conception and articulation. In that way, optimal and aesthetically satisfactory design solutions could be obtained. Although Fasttens can simulate the behavior of tensegrity structures, at this stage of development it is cumbersome and inadequate for comprehensive design exploration. The process is deterministic and produces a single optimal solution to a given set of constraints. To comprehensively explore the architectural potential of tensegrity structures, a computational method is needed where global geometry can be transformed in real-time by manipulating the properties of local connections between and within modules. Furthermore, structural feedback is needed to determine which parts of structure are in compression and tension, and to communicate where a given assembly conforms to a state of tension integrity. The designers in the early stage of design process need more intuitive, interactive, flexible tool that should facilitate fast production and evaluation of variant solutions. Though promising, there is a need to develop this tool further before it is directly useful for design application. Full potential of this software could be realised by the development of bidirectional link with standard CAD software, or its implementation as plug-in. In this way the advantages of $\mathrm{CAD}$, especially parametric modelling environment (familiar to designers) could be extended with physical simulations necessary in the case of designing structures characterised by the complex synergy of stresses and form-finding. 
R.B. Fuller, "Tensegrity," Portfolio and Art News Annual 4 (1961): 112-127, 144, 148. Available at: http://www.rwgrayprojects.com/rbfnotes/fpapers/tensegrity/tenseg01.html; R. B. Fuller, Tensile-integrity structures, U.S. Patent Patent 3,139,957. 13 November, 1962.

D. G., Emmerich, Construction de réseaux autotendants. French Patent Patent 1,377,290. 28 September, 1964; D. G., Emmerich, Structures linéaires autotendants. French Patent Patent 1,377,291. 28 September, 1964.

K., Snelson, Continuous tension, discontinuous compression structures. U.S. Patent Patent 3,169,611. 16 February, 1965.

M., Nestorović, Integralno zategnuti (Tensegriti) konstruktivni sistemi I i II (Beograd: Arhitektonski fakultet Univerziteta u Beogradu, 1994).

B., Kolarevic, Architecture in the Digital Age: Design and Manufacturing (Taylor \& Francis, 2005); M., Bechthold, Innovative Surface Structures: Technologies and Applications (Taylor \& Francis, 2008). 
W. J. Lewis, Tension structures. Form and Behaviour (London: Thomas Telford, 2003).

M., Bechthold, Innovative Surface Structures: Technologies and Applications.

G. Minke, “Tensegrity structures," Zodiac 21 (1970); M. Pasarel, Iterative Nonlinear Analysis of a Tensegrity Structure (Guilford, England: University of Surrey, 1977); R. Motro, "Tensegrity Systems for Double-Layer Space Structures," in Proceedings of International Conference on the Design and Construction of Non-conventional Structures, edited by H.V. Topping (Edinburgh, Scotland: Civil-Comp Press. 1987); R. Motro, "Structural morphology of tensegrity systems," International Journal of Space Structures 11 (1-2) (1996): 25-32; R. Motro, “Tensegrity: The State of the Art," Space Structures 5 (2002): 97-106; R. Motro, Tensegrity: Structural Systems for the Future (London Page Science: Kogan, 2003); R. Motro, C. Bernard, Conception en structures. Rapport d'activités 1999-2002 (Montpellier: Université Montpellier II: Laboratoire de Mécanique et Génie Civil, 2002); A. Hanaor, "Preliminary Investigation of Double-Layer Tensegrities," in Proceedings of International Conference on the Design and Construction of Non-conventional Structures, edited by H.V. Topping (Edinburgh: Scotland: Civil-Comp Press, 1987); A. Hanaor, "Prestressed Pin-Jointed Structures - Flexibility Analysis and PrestressDesign," Computers and Structures 28 (1988): 757-769; A. Hanaor, "Aspects of Design of Double-Layer Tensegrity Domes," International Journal of Space Structures 7 (1992): 101-113; A. Hanaor, "Geometrically Rigid Double-Layer Tensegrity Grids," International Journal of Space Structures 9 (1994): 227-238; M. Nestorović, Integralno zategnuti (Tensegriti) konstruktivni sistemi I i II (Beograd: Arhitektonski fakultet Univerziteta u Beogradu, 1994); M. Nestorović, "Integralno zategnuti (tensegriti) konstruktivni sistemi sa bezmomentnim konturama" (PhD diss., Arhitektonski fakultet Univerziteta u Beogradu, 1990); M. Nestorović, "Metallic Integrally Tensioned (Tensegrity) Cupola," in Proceedings of International Conference on the Design and Construction of Non-conventional Structures, edited by H.V. Topping (Edinburgh: Scotland: Civil-Comp Press, 1987); M. Levy, and G. and F. T. Jing, Castro, "HyparTensegrity Dome, Optimal Configurations," Proceeding of the International IASS Symposium. Copenhagen, Denmark, 1991: 125-128; M. Levy, “The Lightest Retractable Roof," IABSE Symposium, Places of Assembly and Long-Span Building Structures, 1994: 43-47; S. Pellegrino," A class of tensegrity domes," International Journal of Space Structures 7 (2) (1992): 127-142; M. I. Kawaguchi, Tatemichi and P. S. Chen, "Optimum shapes of a cable dome structure," Engineering Structures 21 /8 (1999): 719-725; K. A. Liapi, “A Visualization Method For The Morphological Exploration Of Tensegrity Structures," in Proceedings of the Fifth International Conference on Information Visualization. 2001: 523-528.

D. Veenendaal and P. Block, "An overview and comparison of structural form finding methods for general network," International Journal of Solids and Structures 49 (2012): 3741-3753.

R. Motro, "Tensegrity Systems for Double-Layer Space Structures."

N. Vassart, and R. Motro, "Multiparametered Formfinding Method: Application to Tensegrity Systems," International Journal of Space Structures 14/2 (1999): 147-154.

A. Hanaor, "Prestressed Pin-Jointed Structures - Flexibility Analysis and PrestressDesign," Computers and Structures 28 (1988): 757-769.

A. G. Tibert, and S. Pellegrino, "Review of Form-Finding Methods for Tensegrity Structures," International Journal of Space Structures 18/4 (2003): 209-223.

A. Killian and J. Ochsendorf, "Particle-Spring Systems for Structural Form-Finding," Journal of the International Association for Shell and Spatial Structures 46 (2005): 147.

T. D. Sterk, “CAAD for Responsive Architecture," Joint Study Report 2005-2006 Auto-deskSystems (2007): 66-70.

R. Motro, "Tensegrity: The State of the Art."

R.B. Fuller, Synergetics: Explorations in the Geometry of Thinking (New York: MacMillan Publishing Co., Inc, 1975). Available at: http://www.rwgrayprojects.com/synergetics/synergetics. 
html.

M. Bechthold, Innovative Surface Structures: Technologies and Applications.

R. B. Fuller, Synergetics: Explorations in the Geometry of Thinking

J. Milošević, and M. Nestorović, "Reverse Biomimetic Analogies in Design of Architectural Structures," in Keeping up with technologies in the context of urban and rural synergy [Elektronski izvor] : book of conference proceedings / [4th International academic conference] Places and technologies 2017, 707-715.(Sarajevo: Arhitektonski fakultet Univerziteta u Sarajevu, 2017).

D. E. Ingber and J. D. Jamieson, "Cells as a Tensegrity Structures: Architectural Regulation of Histodifferentiation by Physical Forces Transduced Over Basement Membrane," in Gene Expression During Normal and Malignant Differentiation, edited by L. C., Gahmberg, G. C. and Ekblom P. Anderson (Orlando: Academic Press. 1985), 13-32.

Bechthold, M. Innovative Surface Structures: Technologies and Applications. Taylor \& Francis, 2008.

Davidson, S. n.d. Grasshopper: Algorithmic Modeling for Rhino. http://www.grasshopper3d.com/. De Jong, G. Struck: Fundamentals of Elastic Interval Geometry. 1998. Accessed on February 23, 2017. http://lists.squeakfoundation.org/pipermail/squeak-dev/1998-October/015432.html. Emmerich, D. G. Construction de réseaux autotendants. French Patent Patent 1,377,290. 28 September, 1964.

Emmerich, D. G. "Morphologie et Structure." Architecture d'Aujourd'hui 60 (1972): 20-22.

Emmerich, D. G. Structures linéaires autotendants. French Patent Patent 1,377,291. 28 September, 1964.

Fagerstrom, G. "Dynamic Relaxation of Tensegrity Structures." In Proceedings of the 14th International Conference on Computer Aided Architectural Design Research in Asia. 553-562, 2009.

Fuller, R. B. Tensile-integrity structures. U.S. Patent Patent 3,139,957. 13 November, 1962.

Fuller, R.B. Synergetics: Explorations in the Geometry of Thinking. New York: MacMillan Publishing Co., Inc, 1975. Available at: http://www.rwgrayprojects.com/synergetics/ synergetics.html. 
Fuller, R.B. “Tensegrity.” Portfolio and Art News Annual 4 (1961): 112-127, 144, 148. Available at: http://www.rwgrayprojects.com/rbfnotes/fpapers/tensegrity/tenseg01.html.

Fuller, R.B. "Tensegrity." Creative science and technology (1981). Available at: http://www.bfi. org/infullerswords/Tensegrity.pdf.

Haber, R. B. and J. F. Abel. "Initial equilibrium solution methods for cable reinforced membranes. Part I - Formulations.” Computer Methods in Applied Mechanics and Engineering 30 (1982): 263-284.

Hanaor, A. “Aspects of Design of Double-Layer Tensegrity Domes.” International Journal of Space Structures 7 (1992): 101-113.

Hanaor, A. "Geometrically Rigid Double-Layer Tensegrity Grids." International Journal of Space Structures 9 (1994): 227-238.

Hanaor, A. "Preliminary Investigation of Double-Layer Tensegrities." In Proceedings of International Conference on the Design and Construction of Non-conventional Structures, edited by H.V. Topping. Edinburgh: Scotland: Civil-Comp Press, 1987.

Hanaor, A. "Prestressed Pin-Jointed Structures - Flexibility Analysis and PrestressDesign." Computers and Structures 28 (1988): 757-769.

Ingber, D. E. and J. D. Jamieson, “Cells as a Tensegrity Structures: Architectural Regulation of Histodifferentiation by Physical Forces Transduced Over Basement Membrane.” In Gene Expression During Normal and Malignant Differentiation, edited by L. C., Gahmberg, G. C. and Ekblom P. Anderson, 13-32. Orlando: Academic Press, 1985.

Ingber, D. E. "The Architecture of Life." Scientific American Magazine (1998). Available at: http://vv.arts.ucla.edu/projects/ingber/ingber.html.

IxRay, ltd. RhinoMemebrane: Form-finder plugin and Grasshopper advanced component, 2014. Available at: $\underline{\text { http: } / / \text { www.ixray-ltd.com } / \text { index.php?option }=\text { com content } \& v i e w=\operatorname{article} \& i d=82 \&}$ Itemid=521.

Kawaguchi, M., I.,Tatemichi and P.S. Chen. "Optimum shapes of a cable dome structure." Engineering Structures 21 /8 (1999): 719-725.

Killian, A. and Ochsendorf, J. "Particle-Spring Systems for Structural Form-Finding." Journal of the International Association for Shell and Spatial Structures 46 (2005): 147.

Kolarevic, B. Architecture in the Digital Age: Design and Manufacturing. Taylor \& Francis, 2005.

Levy, M. "The Lightest Retractable Roof." IABSE Symposium, Places of Assembly and LongSpan Building Structures, 1994. 43-47.

Levy, M., and G. and F. T.Jing, Castro. "Hypar-Tensegrity Dome, Optimal Configurations." Proceeding of the International IASS Symposium. Copenhagen, Denmark. 125-128, 1991.

Lewis, W. J. Tension structures. Form and Behaviour. London: Thomas Telford, 2003.

Liapi, K. A. "A Visualization Method For The Morphological Exploration Of Tensegrity Structures." In Proceedings of the Fifth International Conference on Information Visualization. 523-528, 2001.

Milošević, J. and M. Nestorović. "Reverse Biomimetic Analogies in Design of Architectural Structures." In Keeping up with technologies in the context of urban and rural synergy [Elektronski izvor] : book of conference proceedings / [4th International academic conference] Places and technologies 2017, 707-715. Sarajevo: Arhitektonski fakultet Univerziteta u Sarajevu, 2017.

Minke, G. "Tensegrity structures.” Zodiac 21 (1970).

Motro, R. "Structural morphology of tensegrity systems." International Journal of Space Structures 11 (1-2) (1996): 25-32.

Motro, R. "Tensegrity Systems for Double-Layer Space Structures.” In Proceedings of International Conference on the Design and Construction of Non-conventional Structures, edited by H.V. Topping. Edinburgh, Scotland: Civil-Comp Press. 1987.

Motro, R. Tensegrity: Structural Systems for the Future. London Page Science: Kogan, 2003.

Motro, R. “Tensegrity: The State of the Art.” Space Structures 5 (2002): 97-106.

Motro, R., Bernard, C. Conception en structures. Rapport d'activités 1999-2002, Montpellier: Université Montpellier II: Laboratoire de Mécanique et Génie Civil, 2002. 
Nestorović, M. Integralno zategnuti (Tensegriti) konstruktivni sistemi I i II. Beograd: Arhitektonski fakultet Univerziteta u Beogradu, 1994.

Nestorović, M. "Integralno zategnuti (tensegriti) konstruktivni sistemi sa bezmomentnim konturama" (PhD diss., Arhitektonski fakultet Univerziteta u Beogradu, 1990).

Nestorović, M. "Metallic Integrally Tensioned (Tensegrity) Cupola.” In Proceedings of International Conference on the Design and Construction of Non-conventional Structures, edited by H.V. Topping, 53. Edinburgh, Scotland: Civil-Comp Press, 1987.

Pasarel, M. Iterative Nonlinear Analysis of a Tensegrity Structure. Guilford, England: University of Surrey, 1977.

Pellegrino, S. “A class of tensegrity domes.” International Journal of Space Structures 7 (2) (1992): 127-142.

Piker, D. n.d. Grasshopper: Algorithmic Modeling for Rhino - Kangaroo. http://www. grasshopper3d.com/group/kangaroo.

Pugh, A. An introduction to tensegrity. Los Angeles, London: University of California press Berkeley, 1976.

RobertMcNeel\&Associates. n.d. https://www.rhino3d.com/.

Seebohm, T. "Tensegrity Complexity." In On Growth and Form: Organic Architecture and Beyond, autor P. and Bonnemaison, S. Beesley, 126-139 (Tuns Press and Riverside Architectural Press, 2008).

Shea, K., Fest, E. and Smith, I. F. C. "Developing intelligent tensegrity structures with stochastic." Advanced Engineering Informatics 16/1 (2002): 21-40.

Snelson, K. Continuous tension, discontinuous compression structures. U.S. Patent Patent 3,169,611. 16 February 1965.

Sterk, T. D. "CAAD for Responsive Architecture.” Joint Study Report 2005-2006 Auto-deskSystems (2007): 66-70.

Tibert, A. G. and Pellegrino, S. "Review of Form-Finding Methods for Tensegrity Structures." International Journal of Space Structures 18 /4 (2003): 209-223.

Vassart, N. and Motro, R. "Multiparametered Formfinding Method: Application to Tensegrity Systems.” International Journal of Space Structures 14 /2 (1999): 147-154.

Veenendaal, D., Block, P. “An overview and comparison of structural form finding methods for general networks.” International Journal of Solids and Structures (49): 3741-3753. 


\section{RAČUNARSKO PROJEKTOVANJE I ANALIZA TENSEGRITI STRUKTURA Jelene Milošević, Đorđe Nedeljković}

Rad prikazuje primenu računarskih alata u projektovanju i analizi integralno zategnutih (tensegriti) struktura. Proces oblikovanja ovog specifičnog tipa prostornih struktura određen je razmatranjem interelacije forma-struktura. Iz tog razloga, održivi pristup njihovom projektovanu podrazumeva primenu alata koji mogu da prikazuju geometriju i simuliraju fizičko ponašanje ovih struktura. U skladu sa tim, kroz istraživanje smo testirali primenu računarskog alata Fasttens u projektovanju tensegriti struktura. Fasttens program je zasnovan na računarskoj procedure za nelinearnu analizu tensegriti sistema koju je originalno razvio dr Miodrag Nestorović. Kako bi pokrenuli originalni program napisan u Turbo Paskalu, izvršili smo emulaciju, korišćenjem emulatora DOSBox. Primena alata testiran je u projektovanju konkretne tensegriti strukture. Prikazani dizajn i numerički eksperiment potvrdio je efikasnost predloženog pristupa.

KLJUČNE REČI: TENSEGRITI STRUKTURE, PROJEKTOVANJE STRUKTURA, RAČUNARSKO PROJEKTOVANJE, RAČUNARSKA ANALIZA, FASTTENS

UTICAJ MODULA ELASTIČNOSTI MEMBRANSKOG MATERIJALA NA UGIBE MEMBRANE POD DEJSTVOM KONCENTRISANE SILE

\section{Vuk Milošević, Biserka Marković}

Svojstva membranskih konstrukcija uglavnom su definisana karakteristikama membranskog materijala. Jedna od najvažnijih karakteristika membranskog materijala je modul elastičnosti. U ovom radu prikazano je istraživanje odnosa modula elastičnosti membranskog materijala i ugiba membrane pri dejstvu koncentrisane sile. Ispitivanje je izvršeno na numeričkim modelima u specijalizovanom softveru. Vrednost modula elastičnosti je varirana, a promene ugiba membrane su praćene. Takođe, menjana je i orijentacija membranskog materijala i tip ivičnih oslonaca. Dobijeni rezultati pomogli su u razumevanju uticaja modula elastičnosti membranskog materijala na ugibe membrane pod dejstvom koncentrisane sile.

KLJUČNE REČI: MEMBRANSKE KONSTRUKCIJE, ZATEGNUTE KONSTRUKCIJE, MODUL ELASTIČNOSTI, UGIBI, KONCENTRISANA SILA 